\title{
ЛИЧНОЕ ПОДСОБНОЕ ХОЗЯЙСТВО КАК ИСТОЧНИК ДОХОДА
}

\author{
Лушникова Ольга Леонидовна, \\ oltolt@mail.ru \\ Хакасский научно-исследовательский институт языка, литературы и истории, \\ Россия, 655017, г. Абакан, ул. Щетинкина, 23
}

Лушникова Ольга Леонидовна, кандидат социологических наук, старший научный сотрудник сектора экономики и социологии Хакасского научно-исследовательского института языка, литературы и истории.

Сложные социально-экономические условия, связанные с высоким уровнем безработицы, ставят современных сельчан перед непростым выбором: переезжать в город, работать вахтовым методом, жить за счет случайных заработков, заниматься личным подсобным хозяйством или искать альтернативные источники заработка, в том числе нелегальные. В научной литературе можно встретить как минимум две точки зрения на роль личного подсобного хозяйства: отношение к нему как к вынужденной стратегии выживания и представление о нем как о дополнительном источнике дохода. Цель данной статьи - оценить потенциал личного подсобного хозяйства в качестве источника дохода. Методы: эмпирической базой исследования послужили материалы социологического опроса сельского населения Хакасии (2018 г.). Для исследования обозначенной проблемы из общей выборки были отобраны следующие группы сельчан, у которых: единственный источник дохода - личное подсобное хозяйство; зарплата; социальные пособия; источники дохода - и зарплата, и личное подсобное хозяйство. Также использовались статистические данные. Результаты: хозяйства населения значительно влияют на сельское хозяйство региона - на их долю приходится две трети всей сельскохозяйственной продукции, они являются основными производителями овощей, молока и мяса. Оказалось, что количество скота в хозяйстве положительно коррелирует с уровнем материального достатка. Больше всего скота держат сельчане, единственным источником которых является личное хозяйство, а меньше всего - живущие на одну зарплату. Вместе с тем наличие нескольких источников дохода положительно сказывается на материальном положении сельчан и заметно повышает уверенность в будущем.

Ключевые слова: Личное подсобное хозяйство, зарплата, социальные пособия, источники доходов, скот, село, Хакасия.

\section{Постановка проблемы}

В условиях безработицы у современных сельчан небольшой выбор: заниматься личным подсобным хозяйством, работать вахтовым методом, жить за счет случайных заработков, искать альтернативные источники доходов (в т. ч. нелегальные) или переезжать в город. Цель данной статьи - оценить потенциал личного подсобного хозяйства в качестве источника дохода.

\section{ЛПХ как вынужденная стратегия или как дополнительный источник дохода}

В научной литературе можно встретить как минимум две точки зрения на роль личного подсобного хозяйства (ЛПХ). Первая - отношение к ЛПХ как к вынужденной стратегии выживания сельского населения [1-3]. Из-за отсутствия работы сельские жители просто вынуждень заниматься личным хозяйством. ЛПХ позволяет закрыть часть потребностей в пропитании (овощи, яйца, молоко). Некоторым сельчанам удается конвер- 
тировать продукцию ЛПХ в денежный эквивалент, продавая часть производимой продукции. Причем, по мнению О.В. Нечипоренко, продаются зачастую не излишки, а часть необходимого для воспроизводства семьи, а полученный денежный доход, как правило, используется не для производительных, а для потребительских целей [1]. При отсутствии других источников дохода (например, случайных заработков, социальных пособий и т. д.) ЛПХ становится единственным способом существования сельского населения.

Вторая точка зрения - взгляд на ЛПХ как на дополнительный (неосновной) источник дохода [4-6]. По подсчетам С.А. Шарипова, продукция ЛПХ дает от 20 до 40 \% всех доходов семьи [7]. Однако возможности получения прибыли от ЛПХ зависят от разных факторов. Например, присутствие в домохозяйстве нескольких взрослых людей как трудоспособного, так и - особенно - пенсионного возраста увеличивает такие возможности и способствует росту товарности ЛПХ [8]. Это вполне очевидно, поскольку для ведения хозяйства нужны рабочие руки и много времени. С одной стороны, свобода от трудового участия имеет свои достоинства: позволяет содержать на подворье больше живности, возделывать солидные полевые участки за пределами села, торговать продуктами своего хозяйства, получать живые деньги, эффективно решать стратегические цели семьи [9]. Но с другой стороны, занятость кого-нибудь из членов семьи на сельскохозяйственном предприятии положительно сказывается на ведении ЛПХ, поскольку это предполагает льготный доступ к приобретению фуража для животных своего хозяйства [10]. Зарубежные исследования тоже доказывают, что домохозяйства, имеющие источники доходов не только от сельскохозяйственной деятельности, являются более жизнеспособными $[11,12]$. П.П. Великий и В.Л. Шабанов отмечают, что отсутствие работы у одного взрослого часто является результатом его личного выбора и занятость в ЛПХ в этом случае становится заменой официальной занятости, однако отсутствие работы у двоих взрослых, скорее всего, это свидетельство временной безработицы, а не самозанятости в ЛПХ [6].

По данным исследований, основная часть ЛПХ ориентирована на самообеспечение продовольствием, что связано с трудностями сбыта производимой продукции [13]. В большинстве своем содержать скот не для собственного потребления оказывается невыгодно, поскольку не всегда удается продать произведенную сельхозпродукцию. По мнению Н.Е. Покровского и В.А. Шиловой, низкая товарность домашних хозяйств связана с тем, что они практически полностью вытеснены агрохолдингами и крупными коммерческими фермами из товарно-рыночных отношений [14]. Исследователи вообще считают, что организация сельскохозяйственного производства на началах самозанятости - довольно сложное занятие, требующее сил и денег, поэтому более доступны сельским жителям, например откорм молодняка и птицы по договорам подряда с сельскохозяйственными предприятиями [15].

\section{Эмпирическая база исследования}

Эмпирическую базу исследования составили материалы социологического опроса сельских жителей Хакасии 2018 г. Опрос проводился во всех сельских районах республики. Выборка квотная (по полу и возрасту). Всего было опрошено 1000 чел. Однако для изучения поставленной проблемы были отобраны следующие группы сельчан: сельчане, у которых единственным источником дохода является ЛПХ; сельчане, у которых единственным источником дохода является зарплата; сельчане, у которых единственным источником дохода являются социальные пособия; сельчане, у которых источниками дохода являются и зарплата, и ЛПХ. В результате такого отбора анализировались данные 382 анкеты. 


\section{Роль ЛПХ в сельском хозяйстве Хакасии}

Согласно статистическим данным, в Хакасии основной объем сельхозпродукции (65,5 \%) приходится на хозяйства населения, хотя на общероссийском уровне ситуация иная: больше половины объема продукции производят сельскохозяйственные организации (рис. 1).

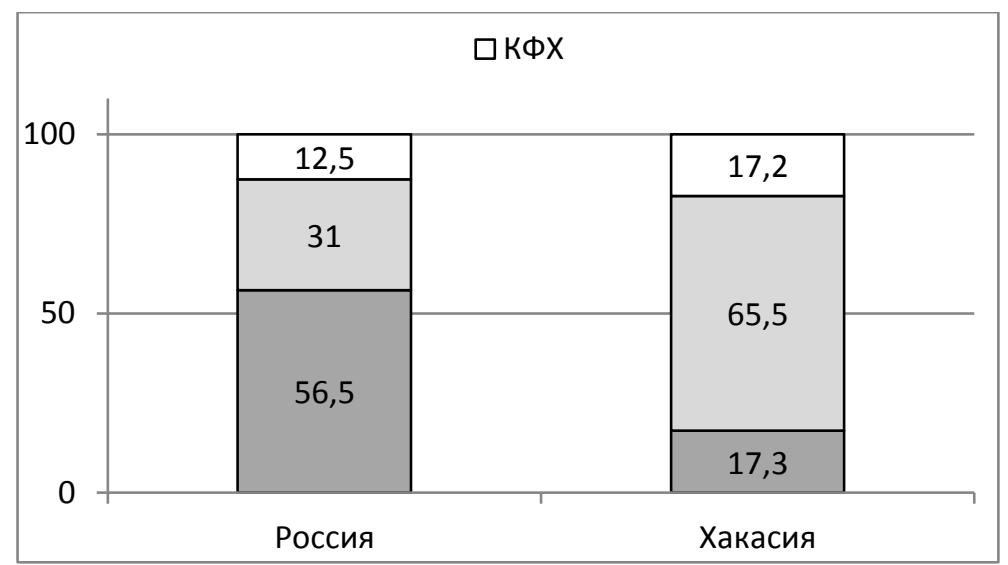

Puc. 1. Структура продукции сельского хозяйства по категориям хозяйств (2018 2.) [16]

Fig. 1. Structure of agricultural products by farm categories (2018)

В Хакасии хозяйства населения являются основными производителями картофеля, овощей, молока, скота и птицы, однако в выращивании зерновых культур и производстве яиц лидируют сельскохозяйственные организации (табл. 1).

Таблища 1. Структура производства основных видов сельскохозяйственной продукции Хакасии по категориям хозяйств (2018 г.), в процентах от общего объема производства $[17,18]$

Table 1. Structure of production of the main types of agricultural products of Khakassia by categories of farms, 2018 (as a percentage of total production)

\begin{tabular}{|c|c|c|c|c|}
\hline $\begin{array}{c}\text { Виды сельскохозяйственной } \\
\text { продукции } \\
\text { Types of agricultural products }\end{array}$ & $\begin{array}{c}\text { Сельскохозяйственные } \\
\text { организации } \\
\text { Agricultural } \\
\text { organizations }\end{array}$ & $\begin{array}{c}\text { Хозяйства } \\
\text { населения } \\
\text { Households of } \\
\text { the population }\end{array}$ & $\begin{array}{c}\text { Крестьянские } \\
\text { (фермерские) } \\
\text { хозяйства } \\
\text { Peasant farms }\end{array}$ & $\begin{array}{c}\text { Итого } \\
\text { Total }\end{array}$ \\
\hline $\begin{array}{l}\text { Зерновые и зернобобовые } \\
\text { культуры (в весе после до- } \\
\text { работки) } \\
\text { Cereals and leguminous crops } \\
\text { (in weight after completion) }\end{array}$ & 62,4 & 0,0 & 37,6 & 100,0 \\
\hline Картофель/Potato & 0,6 & 92,5 & 7,0 & 100,0 \\
\hline $\begin{array}{l}\text { Овощи открытого и закры- } \\
\text { того грунта } \\
\text { Vegetables of open and closed } \\
\text { ground }\end{array}$ & 0,5 & 75,9 & 23,6 & 100,0 \\
\hline $\begin{array}{l}\text { Скот и птица на убой } \\
\text { (в убойном весе) } \\
\text { Cattle and poultry for slaugh- } \\
\text { ter (in slaughter weight) }\end{array}$ & 7,9 & 70,5 & 21,6 & 100,0 \\
\hline Молоко/Milk & 18,5 & 68,8 & 12,7 & 100,0 \\
\hline Яйца/Eggs & 69,8 & 29,5 & 1,8 & 100,0 \\
\hline
\end{tabular}


Вообще разведение скота в сельской местности является традиционным видом хозяйствования, и в целом сельское хозяйство региона имеет животноводческую направленность. На его долю приходится 69,2 \% всей производимой сельхозпродукции [18]. В регионе также действует несколько программ по поддержке ЛПХ. В рамках программы развития овцеводства подворьям предоставляются овцы на два года, по истечении которых они должны передать такое же количество овец другим подворьям. Другая программа действует для жителей малых и отдаленных сел региона: подворьям, содержащим скот, выплачивается денежная компенсация.

Результаты исследования показали, что больше всего скота у опрошенных, основным источником дохода которых является ЛПХ, меньше всего скота - у тех, кто живет только на одну зарплату (рис. 2).

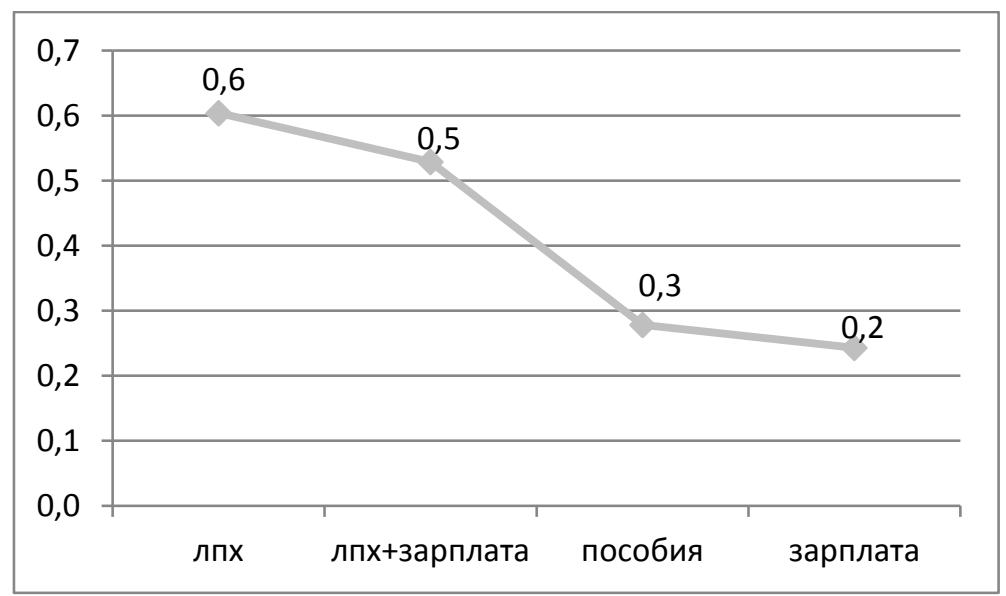

Pис. 2. Среднее количество скота у сельчан с разными источниками доходов, в \% от опрошенных

Fig. 2. Average number of livestock for villagers with new sources of income, in $\%$ of the respondents

Однако у сельчан, имеющих в качестве источников дохода и зарплату, и ЛПХ, больше скота, чем у живущих только на зарплату. Это подтверждается и другими исследованиями. Например, зарубежные исследования доказывают, что наличие дополнительных источников, помимо собственного хозяйства, заметно повышает его товарность и делает более устойчивым в кризисные периоды [19]. П.П. Великий отмечает: несмотря на то, что некоторая доля семей сознательно прекратила трудовые отношения с крупхозами, кто-нибудь из членов семьи всегда остается в составе персонала сельскохозяйственных предприятий, поскольку это предполагает льготный доступ к приобретению фуража для животных своего хозяйства [10]. Действительно, самой большой трудностью при ведении хозяйства для опрошенных является нехватка денег на покупку кормов для домашних животных (39 \%). Примерно каждый пятый сельчанин испытывает необходимость при ведении хозяйства в технике (например, трактора). А четверть опрошенных ответила, что у них просто нет сил и времени заниматься хозяйством. Вместе с тем результаты показали, что количество скота положительно коррелирует с уровнем материального положения опрошенных (коэффициент корреляции по Пирсону $r=0,329 *$ ) (рис. 3).

Среди бедных сельчан (кому денег едва хватает на питание) меньше половины имеют в своем хозяйстве скот, тогда как среди зажиточных - таковых две трети. 


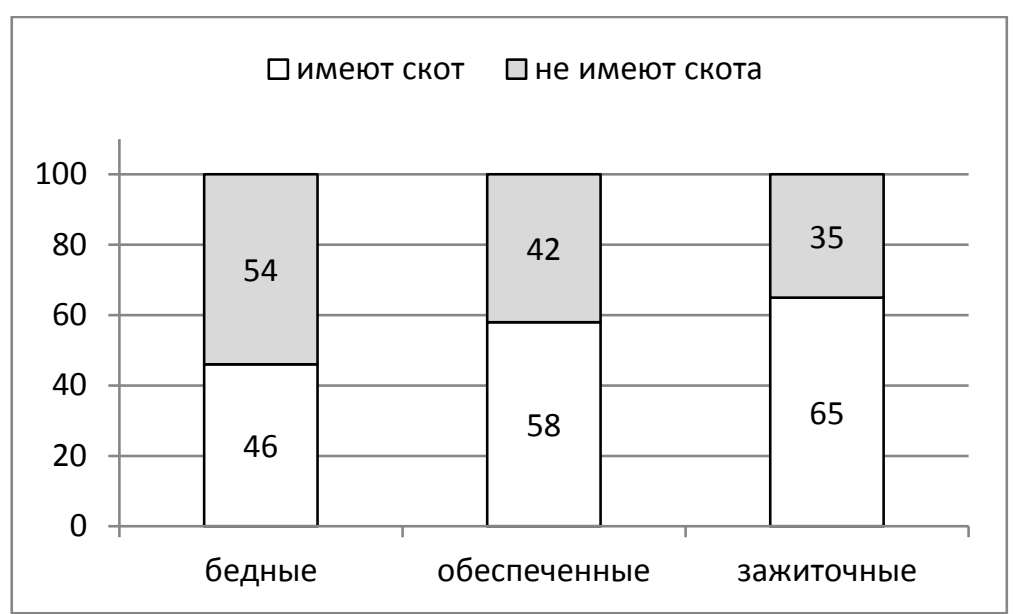

Рис. 3. Сельчане, имеющие и не имеющие скот, в \% от опрошенных

Fig. 3. Villagers with and without livestock, in \% of the respondents

С одной стороны, можно предположить, что именно более высокий уровень материального положения позволяет содержать на подворье больше скота. С другой стороны, возможно и иное: наличие животных повышает уровень достатка сельчан. Вопрос в готовности сельчан заниматься разведением скота. Оказалось, что опрошенные, основным источником дохода которых является зарплата или пособия, отличаются более пассивными установками по отношению к жизни. Среди них каждый десятый прилагает в своей жизни минимум усилий - «только, чтобы выжить», среди ведущих ЛПХ таковых не больше $3 \%$.

Сельчане, единственным источником которых является только ЛПХ, выше оценивают свои возможности - жить только за счет своего хозяйства (рис. 4). С одной стороны, это можно оценивать как более высокий потенциал, но с другой - возможно, это результат безвыходного положения. Из-за отсутствия работы для них это единственный возможный способ выживания.

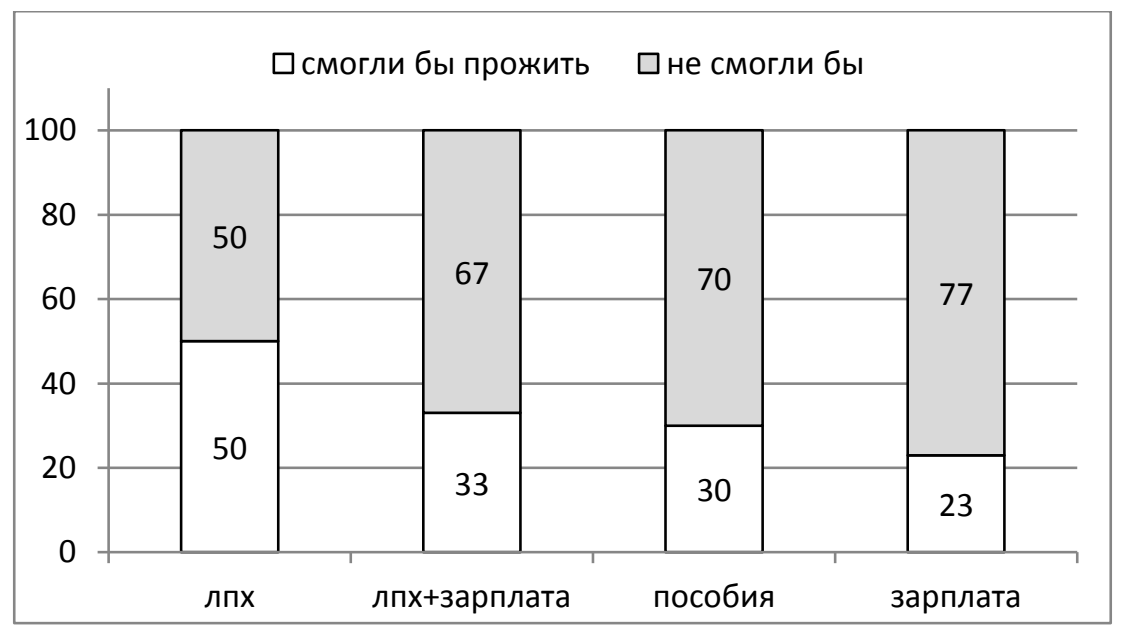

Puc. 4. Распределение ответов на вопрос «Смогли бы Вы прожить только за счет ЛПХ?», в \% от опрошенных

Fig. 4. Distribution of answers to the question «Would you be able to live only at the expense of Personal subsidiary farming?», in \% of respondents 
Сельчане, имеющие несколько источников дохода (и ЛПХ, и зарплату), ниже оценивают свои возможности - прожить только за счет хозяйства. Но наряду с этим они отличаются более активной жизненной позицией: среди них абсолютное большинство $(92 \%)$ делает все, чтобы жить лучше. Как результат - они реже берут деньги взаймы, меньше боятся потерять работу, больше уверены в будущем и т.д. Другими словами, наличие «запасного аэродрома» в виде ЛПХ положительно сказывается на благополучии сельчан.

\section{Выводы}

Согласно полученным результатам, основным источником средств существования ЛПХ является для $13 \%$ опрошенных, еще для $23 \%$ он служит дополнительным источником дохода. Отвечая на поставленный вначале вопрос, можно заключить, что в нынешних условиях прожить в селе только за счет личного хозяйства можно, хотя и сложно. На уровне региональной власти создаются условия для развития ЛПХ: действуют программы, мотивирующие население разводить скот. Поэтому благополучие сельских жителей во многом зависит от их готовности заниматься развитием своих подворий. Ведь, как отмечают исследователи, жизненные стратегии бедного человека зависят не только от объективных условий его жизни, но и от свойств его личности [20].

Вместе с тем необходимы и другие меры повышения мотивации для сельского населения, причем на уровне федеральной власти. Одной из таких мер может стать назначение пенсионного пособия за ведение личного подсобного хозяйства наряду с обычным трудовым стажем. Такая мера повысит мотивацию сельских жителей заниматься развитием своих хозяйств, которым они смогут уделять больше времени, высвобожденному от официальной занятости.

\section{СПИСОК ЛИТЕРАТУРЫ}

1. Нечипоренко О.В. Подсобные хозяйства сельского населения в контексте практик социальной адаптации // Вестник Новосибирского государственного университета. Серия «Философия». - 2013. T. 11. - № 2. - C. 86-92.

2. Жалсанова В.Г. Личное хозяйство сельских жителей: способ выживания или способ развития? (по материалам социологических исследований в Республике Бурятия) // Социодинамика. - 2018. № 9. - С. 1-7.

3. Забелина О.В., Конкина В.С. Трудовой потенциал сельских территорий: текущее состояние и прогноз развития // Вестник Тверского государственного университета. Серия «Экономика и управление». - 2016. - № 4. - С. 110-116.

4. Бильтрикова А.В. Проблема бедности сельского населения Республики Бурятия // Современные исследования социальных проблем: электронный журнал. - 2012. - № 9 (17). - С. 31-43.

5. Красилов В.М., Васильева Т.О. Трудовой потенциал и формы занятости сельского населения Новосибирской области // Вестник Сибирского университета потребительской кооперации. - 2018. № 2 (24). - С. 47-57.

6. Великий П.П., Шабанов В.Л. Особенности аграрной самозанятости. Опыт социологического исследования самостоятельного хозяйствования сельских семей // Историческая и социальнообразовательная мысль. - 2019. - Т. 11. - № 4. - С. 105-121.

7. Шарипов С.А. Рост народонаселения и формирование трудовых ресурсов сельских территорий // Агропродовольственная политика России. - 2017. - № 1 (61). - С. 10-17.

8. Шабанов В.Л. Трансформация ЛПХ как источника занятости и доходов сельского населения // Экономика сельского хозяйства России. - 2018. - № 7. - С. 79-84.

9. Великий П.П. Хозяева сельских подворий: дифференциация, проблемы, будущее // Социологические исследования. - 2019. - № 12. - С. 48-60.

10. Великий П.П. Противоречия в жизненном пространстве села: генезис, настоящее, будущее // Региональные агросистемы: экономика и социология. - 2020. - № 4. - С. 67-71. 
11. Osarfo D., Senadza B., Nketiah-Amponsah E. The impact of nonfarm activities on rural farm household income and food security in the upper east and upper west regions of Ghana // Theoretical Economics Letters. - 2016. - № 6. - P. 388-400. DOI: 10.4236/tel.2016.63043

12. Lay J., Schuler D. Income diversification and poverty in a growing agricultural economy: the case of Ghana // Proceedings of the German Development Economics Conference. - Zurich, 2008. - № 39. - P. 1-39.

13. Переселкова 3.Ю. Состояние и перспективы занятости сельского населения Оренбургской области как условие обеспечения продовольственной безопасности региона // Южно-российский журнал социальных наук. - 2018. - Т. 19. - № 3. - С. 37-46.

14. Покровский Н.Е., Шилова В.А. Динамика «человеческого капитала» в сельских поселениях России: проблемы сохранения и развития // Социологическая наука и социальная практика. - 2020. - Т. 8. № 4 (32). - С. 183-198.

15. Незанятое население и самозанятость в Сибирском регионе / Н.М. Воловская, Л.К. Плюснина, А.В.Русина, А.В. Иноземцева // Социологические исследования. - 2015. - № 5 (373). - С. $52-60$.

16. Российский статистический ежегодник / под ред. П.В. Малкова - М.: Росстат, 2019. - 708 с.

17. Хакасский республиканский статистический ежегодник / под ред. Т.В. Шаршовой - Абакан: Красноярскстат, 2019. - 433 с.

18. Республика Хакасия в цифрах, 2020 / под ред. С.И. Березовской - Красноярск: Красноярскстат, 2021. - $180 \mathrm{c}$.

19. Determinants and measurement of food insecurity in Nigeria: some empirical policy guide / P. Amaza, J. Umeh, J. Helsen, A. Adejobi. - Gold Coast: International Association of Agricultural Economists Annual Meeting, 2006. - 15 p. URL: https://ideas.repec.org/p/ags/iaae06/25357.html (дата обращения: 10.01.2020).

20. Зубкевич Л.А. Влияние бедности как социального феномена на мировоззрение людей в современных условиях общественного развития (социально-философский анализ) // Векторы благополучия: экономика и социум. - 2019. - № 4 (35). - С. 105-122.

Поступила 21.03.2021 2. 
UDC 332.66:330.564.24:635.018

\title{
PERSONAL SUBSIDIARY FARMING AS A SOURCE OF INCOME
}

\author{
Olga L. Lushnikova, \\ oltolt@mail.ru \\ Khakass Research Institute of Language, Literature and History, \\ 23, Shchetinkin street, Abakan, 655017, Russia
}

Olga L. Lushnikova, Cand. Sc., senior researcher Khakass Research Institute of Language, Literature and History.

Difficult socio-economic conditions associated with a high level of unemployment pose modern villagers with a difficult choice: to move to the city, to work on a rotational basis, to live off odd jobs, to engage in personal subsidiary farming, or to look for alternative sources of income, including illegal ones. In the scientific literature, one can find at least two points of view on the role of personal subsidiary farming: the attitude to it as to the forced strategy of survival and the idea of it as an additional source of income. The purpose of this article is to assess the potential of personal subsidiary farming as a source of income. Methods. The empirical basis of the study was the materials of a sociological survey of the rural population of Khakassia in 2018. To study the indicated problem, the following groups of villagers were selected from the general sample: villagers whose only source of income is their personal subsidiary farming; villagers whose only source of income is wages; villagers whose only source of income is social benefits; villagers whose sources of income are both wages and personal subsidiary farming. Statistical data were also used. Results. Households of the population play a significant role in agriculture in the region, they account for two-thirds of all agricultural products. They are the main producers of vegetables, milk and meat. It turned out that the number of livestock on the farm is positively correlated with the level of material wealth. Most of the livestock is kept by the villagers, the only source of which is the private economy, and least of all - living on one salary. At the same time, the presence of several sources of income (both the economy and the salary) has a positive effect on the material situation of the villagers and significantly increases confidence in the future.

Key words: Personal subsidiary farming, salary, social benefits, sources of income, livestock, cattle, village, Khakassia.

\section{REFERENCES}

1. Nechiporenko O.V. Podsobnye khozyaystva selskogo naseleniya v kontekste praktik sottsialnoy adaptatsii [Part-time farms of rural population in the context of social adaptation practices]. Vestnik Novosibirskogo gosudarstvennogo universiteta. Seriya «Filosofiya», 2013, vol. 11, no. 2, pp. 86-92.

2. Zhalsanova V.G. Lichnoe khozyaystvo selskikh zhiteley: sposob vyzhivaniya ili sposob razvitiya? (po materialam sotsiologicheskikh issledovaniy v Respublike Buryatiya) [Personal economy of rural residents: a way of survival or a way of development? (Based on the materials of sociological research in the Republic of Buryatia]. Sotsiodinamika, 2018, no. 9, pp. 1-7.

3. Zabelina O.V., Konkina V.S. Trudovoy potenytsial selskikh territoriy: tekushchee sostoyanie i prognoz razvitiya [Labour capacity of rural territories: current state and development forecast]. Vestnik Tverskogo gosudarstvennogo universiteta. Seriya «Ekonomika i upravlenie», 2016, no. 4, pp. 110-116.

4. Biltrikova A.V. Problema bednosti selskogo naseleniya Respubliki Buryatiya [The Problem of poverty of the rural population of the Republic of Buryatia]. Sovremennye issledovaniya sotsialnykh problem: elektronny zhurnal, 2012, no. 9 (17), pp. 31-43.

5. Krasilov V.M., Vasileva T.O. Trudovoy potentsial i formy zanyatosti selskogo naseleniya Novosibirskoy oblasti [Labor potential and forms of employment of rural population in the Novosibirsk Region]. Vestnik Sibirskogo universiteta potrebitelskoy kooperatsii, 2018, no. 2 (24), pp. 47-57.

6. Velikiy P.P., Shabanov V.L. Osobennosti agrarnoy samozanyatosti. Opyt sotsiologicheskogo issledovaniya samostoyatelnogo khozyaystvovaniya selskikh semey [Features of agrarian self-employment. Experience of 
sociological research of the independent economy of rural families]. Istoricheskaya $i$ sotsialnoobrazovatelnaya mysl, 2019, vol. 11, no. 4, pp. 105-121.

7. Sharipov S.A. Rost narodonaseleniya i formirovanie trudovykh resursov selskikh territoriy [Population growth and the formation of rural labor resources]. Agroprodovolstvennaya politika Rossii, 2017, no. 1 (61), pp. 10-17.

8. Shabanov V.L. Transformatsiya LPKh kak istochnika zanyatosti i dokhodov selskogo naseleniya [Transformation of private subsidiary farms is as a source of employment and income of rural population]. Ekonomika selskogo khozyaystva Rossii, 2018, no. 7, pp. 79-84.

9. Velikiy P.P. Khozyaeva selskikh podvoriy: differentsiatsiya, problemy, budushchee [Owners of private farmsteads: differentiation, problems, outlook]. Sotsiologicheskie issledovaniya, 2019, no. 12, pp. 48-60.

10. Velikiy P.P. Protivorechiya v zhiznennom prostranstve sela: genezis, nastoyashchee, budushchee [Contradictions in the living space of the village: genesis, present, future]. Regionalnye agrosistemy: ekonomika $i$ sotsiologiya, 2020, no. 4, pp. 67-71.

11. Osarfo D., Senadza B., Nketiah-Amponsah E. The impact of nonfarm activities on rural farm household income and food security in the upper east and upper west regions of Ghana. Theoretical Economics Letters, 2016, no. 6, pp. 388-400. DOI: 10.4236/tel.2016.63043

12. Lay J., Schuler D. Income diversification and poverty in a growing agricultural economy: the case of Ghana. Proceedings of the German Development Economics Conference Ю Zurich, 2008, no. 39, pp. 1-39.

13. Pereselkova Z.Yu. Sostoyanie i perspektivy zanyatosti selskogo naseleniya Orenburgskoy oblasti kak uslovie obespecheniya prodovolstvennoy bezopasnosti regiona [The State of Employment and its Perspectives for the Rural Population in Orenburg Region as Provision for Agrofood Security]. Yuzhno-rossiyskiy zhurnal sotsialnykh nauk, 2018, vol. 19, no. 3, pp. 37-46.

14. Pokrovsky N.E., Shilova V.A. Dinamika «chelovecheskogo kapitala» v selskikh poseleniyakh Rossii: problemy sokhraneniya i razvitiya [Dynamics of Human Capital in Rural Settlements of Russia: Problems of Preservation and Development]. Sotsiologicheskaya nauka i sotsialnaya praktika, 2020, vol. 8, no. 4 (32), pp. 183-198.

15. Volovskaya N.M., Pliusnina L.K., Rusina A.V., Inozemtseva A.V. Nezanyatoe naselenie i samozanyatost v Sibirskom regione [Unemployed population and self-employment in Siberian Region]. Sotsiologicheskie issledovaniya, 2015, no. 5 (373), pp. 52-60.

16. Rossiyskiy statisticheskiy ezhegodnik [Russian statistical compilation]. Ed. by P.V. Malkov. Moscow, Rosstat Publ., 2019. 708 p.

17. Khakasskiy respublikanskiy statisticheskiy ezhegodnik [Khakass Republic Statistical yearbook]. Ed. by T.V. Sharshova. Abakan, Krasnoyarskstat Publ., 2019. 433 p.

18. Respublika Khakasiya v tsifrakh, 2020 [Republic of Khakassia in numbers]. Ed. by S.I. Berezovskaya. Krasnoyarsk, Krasnoyarskstat Publ., 2021. 180 p.

19. Amaza P., Umeh J., Helsen J., Adejobi A. Determinants and measurement of food insecurity in Nigeria: some empirical policy guide. Gold Coast, International Association of Agricultural Economists Annual Meeting, 2006. 15 p. Available at: https://ideas.repec.org/p/ags/iaae06/25357.html (accessed 10 October 2020).

20. Zubkevich L.A. Impact of poverty as a social phenomenon on the worldview of people in modern conditions of social development (social and philiosophical analisis). Journal of Wellbeing Technologies, 2019, no. 4 (35), pp. 105-122. In Rus.

Received: 21 March 2021. 